\title{
Medicinal Value of Plant Mucilages ${ }^{\dagger}$
}

\section{R. Naviya ${ }^{1}$, Rupadharshini K. ${ }^{1}$, C. Valli Nachiyar ${ }^{1, *}$}

1 Department of Biotechnology, School of Bio and Chemical Engineering, Sathyabama Institute of Science and Technology, Chennai 600119 Tamil Nadu, India

* Correspondence: vnachiyar@gmail.com;

$\uparrow \quad$ Presented at International e-Conference on Bioengineering for Health and Environment (ICBHE 2020)

Received: 5.07.2020; Revised: 10.07.2020; Accepted: 12.07.2020; Published: 15.07.2020

\begin{abstract}
Mucilage [Latin-mucus] is a thick, gelatinous substance produced by nearly all plants and certain microorganisms. It's a polar glycoprotein and an exopolysaccharide, they're generally normal products of metabolism, formed within the cell. They seem to point high quantities in certain plants, animals, seaweeds, fungi, and other microbial sources, where they perform structural and metabolic functions; plant sources, however, provide the most important amounts. The mucilaginous plants contain highly qualified mucilages that have a specific role in pharmacological and industrial applications. In the mercantile world, the usage of pharmaceutical drugs is enhanced in unique ways to fight as resistance against foreign bodies. This paper reviews various mucilaginous plants and their medicinal applications.
\end{abstract}

Keywords: Mucilage; glycoprotein; exopolysaccharide.

(C) 2020 by the authors. This article is an open-access article distributed under the terms and conditions of the Creative Commons Attribution (CC BY) license (https://creativecommons.org/licenses/by/4.0/).

\section{Funding}

This research received no external funding.

\section{Acknowledgments}

This research has no acknowledgment.

\section{Conflicts of Interest}

The authors declare no conflict of interest. 